\title{
Analisis Framing Rencana Pemindahan Ibu Kota Indonesia Dalam Video 'Dilema Ibu Kota Baru: Selamatkan Jakarta, Korbankan Kalimantan? "Pada Channel Youtube Bbc News Indonesia
}

\author{
Lina Wati S.Sos.I., M.IKom, ${ }^{1}$ Sella Yuningsih S.Ikom. ${ }^{2}$ \\ ${ }^{1}$ Universitas Islam Syekh Yusuf, Tangerang, Indonesia \\ ${ }^{2}$ Universitas Islam Syekh Yusuf, Tangerang, Indonesia
}

Email:

linawati@unis.ac.id

yuningsih.sella5@gmail.com

\section{Article Information}

Submmited 2 Juni 2021

Revision 28 Juni 2021

Accepted 29 Juni 2021

Published 28 Desember 2021

\section{Keywords}

Pemindahan Ibu Kota Indonesia, BBC News Indonesia, Framing

\section{ABSTRAKS}

Penelitian ini berjudul Analisis Framing Rencana Pemindahan Ibu Kota Indonesia Dalam Video "Dilema Ibu Kota Baru: Selamatkan Jakarta, Korbankan Kalimantan?” Pada Channel Youtube BBC News Indonesia. Penelitian ini untuk melihat bagaiaman BBC News Indonesia memframing pemberitaan melalui video dengan tema pemindahan ibu kota baru. Teori Konstruksi Realitas Sosial dan Analisis Framing dalam mengupas framing BBC News Indoensia. Objek penelitian adalah Video "Dilema Ibu Kota Baru: Selamatkan Jakarta, Korbankan Kalimantan?” Pada Channel Youtube BBC News Indonesia. Metode yang digunakan dalam penelitian ini adalah metode kualitatif dengan metode analisis framing oleh Zhongdang Pan dan M. Kosicki. Metode analisis Pan dan Kosicki terdiri dari struktur sintaksis, skrip, tematik dan retoris. Hasil penelitian menunjukkan bahwa konstruksi video yang dimuat oleh BBC News Indonesia dapat dilihat dari dua perspektif. Pertama, pemindahan ibu kota ke Kalimantan dilakukan karena Jakarta dianggap sudah tidak layak menjadi ibu kota Indonesia. Kedua, pemindahan ibu kota ke Kalimantan berdampak besar bagi warga adat dan hutan Kalimantan.

\section{Pendahuluan}

Pada tahun 2019, tepatnya 28 Agustus Presiden Joko Widodo secara resmi mengumumkan rencana perpindahan ibu kota negara dari Jakarta. Wilayah Kalimantan 
Timur telah ditetapkan menjadi ibu kota baru Negara Kesatuan Republik Indonesia. Menurut presiden, Ibu kota baru negara Indonesia nantinya akan berada di sebagian kabupaten Penajam Paser Utara dan sebagian kabupaten Kutai Kartanegara di provinsi Kalimantan Timur. Dilansir dari BBC News Indonesia, bahwa Jakarta telah mengalami penurunan wilayah setiap tahunnya, karena pencemaran lingkungan yang sangat amat besar di Jakarta. Selain itu, kemacetan di Jakarta sudah sangat terkenal seantero dunia.

Jakarta dengan kondisi padat, penuh gedung bertingkat yang bersifat baku, minimnya cadangan sumber air menjadi sebuah alasan penting mengenai pemindahan ibu kota. Selain itu 60\% penduduk Indonesia berada di wilayah Jawa, sebab dari alasan tersebut pemindahan ibu kota selayak di luar dari pulau jawa. (Hutasoit, 2018). Harapan pemerintah pada akhir tahun 2020, Ibu kota baru sudah mulai dilakukan pembangunan dan pada tahun 2024 ibu kota baru akan melakukan proses pemindahan (Lipi, 2019).

Wacana pemindahan ibu kota negara ini terus memicu polemik. Perdebatan perpindahan ibu kota menjadi polemik yang tidak bisa diselesaikan, pendapat masyarakat yang beragam merupakan sebuah resiko pemerintah dalam pemindahan ibu kota tersebut. Dampak lain dari pemindahan ibu kota negara ke luar Pulau Jawa terutama terkait dengan kesiapan daerah tujuan dalam aspek infrastruktur yang dibutuhkan untuk mendukung penyelenggaraan pemerintahan. Dari aspek pembiayaan, walaupun pemerintah sudah menyatakan hanya 19,2\% dari total kebutuhan anggaran Rp 446 Triliun ditanggung oleh APBN, namun terdapat resiko penambahan beban anggaran negara apabila terjadi kegagalan pembangunan yang dilakukan oleh pihak swasta (Silalahi, 2019)

Pada kasus di berbagai negara pemindahan ibu kota banyak dilakukan oleh banyak negara, dengan alasan yang berbeda-beda. Contoh berikut memberikan gambaran bahwa pemindahan ibu kota negara itu tidak tabu dan dilakukan dengan tujuan memecahkan permasalahan untuk menuju ke perbaikan dan kemajuan bangsa dan negara.

1) Brasilia ibu kotanya terletak di pedalaman, karena ibu kota lama Rio Jenairo sudah terlalu padat

2) Pemerintah Korea Selatan da;lam tahun 2004 ibu kotanya pindah dari Seoul ke Sejong, meskipun Seoul itu berarti ibu kota dalam bahasa Korea.

3) Ibu kota tradisional secara ekonomi memudar oleh kota pesaingnya, seperti Nanjing oleh Shanghai.

4) Menurunya suatu dinasti atau budaya dapat juga ibu kota yang telah ada mati/pudar/kalah pamor seperti di Babilon dan Cahokia.

Selain ibu kota negara dipindahkan terdapat juga pemindahan sebagian dari kekuasaan pemerintah, contoh berikut dapat dijadikan salah satu alternatif untuk pemecahan masalah yang terkait dengan ibu kota negara.

1) Bolivia: Succre masih ibu kota konstitusional tetapi pemerintahan nasional telah lama ditinggalkan dan beralih ke La Paz. 
2) Chili: Santiago masih dianggap sebagai ibu kota meskipun Kongres Nasionalnya di Valparaiso.

3) Belanda: Amsterdam ibu kota nasional konsitusional, meskipun pemerintahan Belanda, parlemen, istana ratu semuanya terletak di Den Haag.

4) Afrika Selatan: ibu kota administratif di Pretoria, ibu kota legislatifnya di Cape Town dan ibu kota judisialnya di Bloemfontein

Pemindahan sebagian kekuasaan pemerintah di Indonesia sangat dimungkinkan, karena di dalam Undang-Undang Dasar Republik Indonesia dan Amandemennya tidak diatur secara tegas. Dalam Bab II ayat (2) UUD NKRI tertulis: Majelis Permusyawaratan Rakyat bersidang sedikitnya sekali dalam lima tahun di ibu kota negara. Dalam UUD tersebut tidak ada pasal yang menyebutkan dimana dan bagaimana ibu kota negara diatur. Dengan demikian terdapat fleksibilitas yang tinggi dalam mengatur, termasuk memindah ibu kota negara. Dalam pemindahan ibu kota negara tentunya perlu ada alasan yang kuat dan mendasar tentang efektifitas fungsinya.

Seiring pengembangan ibu kota baru ada pula kekhawatiran komunitas adat Suku Paser tentang penggusuran. Salah satunya Dahlia, perempuan Suku Paser yang berumur 23 tahun ini mengaku takut dan cemas dengan adanya proyek pemindahan ibu kota ke Kalimantan. Kekhawatiran komunitas adat Suku Paser dikemukakan dalam sebuah video berdurasi 17 Menit 24 Detik. Video ini diproduksi oleh media BBC News Indonesia pada channel YouTubenya dengan judul "Dilema Ibu Kota Baru: Selamatkan Jakarta, Korbankan Kalimantan?". Video liputan ini telah ditonton sebanyak 390.074 kali dan mendapatkan lebih 2.900 likes, 366 unlikes, dengan jumlah komentar sebanyak 1.937 sejak diunggah pada 6 Maret 2020 lalu.

Video penelurusan mengenai pemindahan Ibu kota Indonesia pada channel YouTube BBC News Indonesia diteliti karena BBC News Indonesia merupakan salah satu media daring yang tertua di Indonesia dan dapat diakses secara massif. Dan juga penelusuran yang dilakukan oleh tim BBC News Indonesia sangat menarik karena dilakukan pada bulan Oktober 2019 dua bulan setelah Presiden RI mengumumkan rencana pemindahan ibu kota, namun videonya baru ditayangkan pada 6 Maret 2020. Hal ini dapat membuktikan bahwa BBC News Indonesia sangat mengedepankan keunggulan pada inovatif dan keaslian berita. Maka dari itu penelitian ini mengkaji video tersebut dengan metode analisis framing model Zhongdang Pan dan Gerald M. Kosicki sebagai fokus penelitian. Peneliti menggunakan analisis framing model Zhongdang Pan dan Gerald M. Kosicki, dengan mengoperasionalkan empat dimensi struktur framing antara lain struktur sintaksis, skrip, tematik dan retoris. Empat dimensi struktur framing tersebut tidak hanya berfokus pada pemaknaan teks, tapi juga menyertakan pendalaman visual sebagai 
perangkat pembingkaian untuk memaknai video "Dilema Ibu Kota Baru: Selamatkan Jakarta, Korbankan Kalimantan?" pada channel YouTube BBC News Indonesia.

\section{Metode Penelitian}

Penelitian ini menggunakan paradigma konstruktivisme karena peneliti ingin mengetahui bagaimana BBC News Indonesia mengemas berita dalam video untuk menemukan bagaimana realitas mengenai pemindahan ibu kota Indonesia tersebut dikonstruksikan, dan dengan cara apa konstruksi tersebut dibentuk. Prinsip konstruktivisme, dimana berita yang ada di media massa merupakan hasil konstruksi sosial dalam artian berita tersebut terdapat unsur ideologi, serta nilai-nilai dari penulis berita dan tidak dipungkiri dari perusahaan berita tersebut. Pemberitaan pada media massa sesuai dengan sudut pandang pembawa berita, perspektif, gaya Bahasa, reorika dan common sense penyampai berita atau pembawa berita serta perusahaan media tersebut. (Karman, 2013). Pandangan konstruksionis menilai bahwa berita yang sampai ke pembaca adalah berita yang subjektif, bukan lagi objektif seperti pandangan para kaum positivisme. Pemilihan metode analisis framing ini karena metode ini merupakan metode yang melihat bagaimana sebuah peristiwa itu dibingkai di dalam pemberitaan. (Leonarda Johanes R.S., 2013)

Penelitian ini menggunakan metode kualiatif sebagai pelengkap penelitian yang dilakukan karena dapat menjawab dengan cara menjabarkan temuan hasil review peneliti terhadap berbagai dokumen yang utamanya adalah video pada channel YouTube BBC News Indonesia mengenai pemindahan ibu kota Indonesia dengan konteks yang alamiah dan berupa uraian deskriptif.

Tradisi penelitian yang digunakan dalam penelitian ini adalah analisis framing Zhongdang Pan dan Ge rald M. Kosicki. Gagasan mengenai framing, pertama kali dilontarkan oleh Beterson tahun 1955. Mulanya, frame didasarkan pada stuktur konseptual dan kepercayaan dengan menyediakan kategori-kategori. Lalu, konsep tersebut dikembangkan oleh Goffman pada 1974, yang mengandaikan frame sebagai kepingankepingan perilaku (strips of behavior) yang membimbing individu dalam membaca realitas. Ada dua kelas utama dari bingkai menurut Goffman, yakni: Alam dan Sosial. Jika alam maka murni karena fisik, jika sosial, maka menggabungkan latar belakang yang menggabungkan kehendak, tujuan, dan pengendalian tujuan dari kecerdasan, dan hal hal yang berkaitan dengan manusia. (Goffman, 1974)

Framing yang dijalankan oleh media dengan menseleksi isu tertentu dan mengabaikan isu yang lain. Media harus menempatkan posisinya sebagai sebuah institusi yang mengedepankan realitas berbasis fakta. Goffman berpendapat bahwa "kita sering menggunakan kata "real" yang dijadikan sebagai kata yang bermakna kontras dengan 
kejadian yang "unreal". Tetapi, jika terjadi sesuatu yang tidak nyata, maka kita tidak perlu merubahnya menjadi hal yang nyata

Analisis framing Pan dan Kosicki ini menjelaskan analisis framing yang sangat mendalam dalam menunjukkan framing pemberitaan. framing Zhongdang Pan dan Ge rald M. Kosicki berpendapat bahwa setiap berita memiliki frame yang berfungsi sebagai pusat dari organisasi ide. Framing berita dapat dilihat dari ciri perangkat framing, di antaranya bagaimana struktur berita dibangun, unsur berita atau yang kita kenal sebagai formula $5 \mathrm{~W}+1 \mathrm{H}$, bentuk kalimat, kata ganti, bahkan grafis sengaja dibuat untuk menonjolkan suatu informasi tersebut. (Defi, 2019)

Model Zhongdang Pan dan Gerald M Kosicki berasumsi bahwa setiap berita mempunyai frame yang berfungsi sebagai pusat organisasi ide. Frame merupakan suatu ide yang dihubungkan dengan elemen yang berbeda dalam tekas berita (kutipan sumber, latar informasi, pemakaian kata atau kalimat tertentu) ke dalam teks secara keseluruhan. Frame berhubungan dengan makna. Bagaimana seseorang memaknai suatu peristiwa, dapat dilihat dari perangkat tanda yang dimunculkan dalam teks. (Sobur, 2009)

Penelitian melalui framing model Zhongdang Pan dan Gerald M. Kosicki dirasa tepat, karena model ini tidak hanya fokus pada pemaknaan teks saja, tetapi turut menyertakan pendalam visual melalui 4 model analisisnya, yaitu : Sintaksis, Skrip, Tematik dan Retoris

1) Sintaksis : berhubungan dengan headline berita, lead berita, latar informasi, pernyataan, opini, kutipan, pengamatan atas peristiwa ke dalam bentuk susunan kalimat. Konsep sintaksis yang paling umum misalnya, headline, menempatkan bagian di atas paling penting (piramida terbalik), lead, latar informasi, sumber, penutup dalam satu kesatuan teks berita secara keseluruhan. Bila dicermati, elemen berita headline merupakan aspek sintaksis yang paling menonjol dan mengindikasikan kecenderungan sebuah berita. Headline yang tepat akan menimbulkan ingatan tentang realitas yang diberitakan itu secara lebih baik. Selain headline konsep sintaksis yang sering dicermati adalah susunan naskah atau struktur skrip yang berkaitan dengan cara jurnalis menuangkan peristiwa ke dalam bentuk berita. Umumnya peristiwa diberitakan sebagai sebuah kisah atau cerita, karena adanya hubungan antar peristiwa . Instrumen framing ketiga menurut Pan dan Kosicki adalah struktur tematik. Instumen ini berhubungan dengan perspektif jurnalis dalam mengungkapkan pandangannya atas peristiwa ke dalam proposisi, kalimat atau hubungan antarkalimat yang membentuk teks secara keseluruhan. Bagi Pan dan Kosicki, berita mirip sebuah pengujian hipotesis peristiwa yang diliput, sumber yang dikutip, dan pernyataan yang 
diungkapkan. Semua pernyataan itu digunakan untuk membuat dukungan yang logis bagi hipotesis yang dibuat. Perangkat paripurna adalah, struktur retoris yang berjalinan dengan bagaimana jurnalis memberikan aksentuasi peristiwa kedalam naskah berita. Dalam perangkat ini misalnya adalah diksi, idiom, metafora, ilustrasi dan sebagainya. Inilah taste jurnalis dalam berkarya. Struktur retoris dari wacana berita menggambarkan pilihan gaya atau kata yang dipilih oleh wartawan untuk menekankan arti yang ingin ditonjolkan oleh wartawan.

2) Skrip : Berhubungan dengan cara wartawan dalam mengisahkan berita dan mengemas peristiwa.

3) Tematik: Hubungan antar kalimat yang membentuk teks secara keseluruhan.

4) Retoris: Berhubungan dengan cara wartawan memakai pilihan kata, grafik dan idiom yang dipakai bukan hanya untuk mendukung tulisan. (Eriyanto, 2002)

Tabel 1

\begin{tabular}{|c|c|c|}
\hline Struktur & Perangkat Framing & Unit Yang Diamati \\
\hline $\begin{array}{l}\text { SINTAKSIS } \\
\text { Cara Wartawan dalam } \\
\text { Menyusun Berita }\end{array}$ & 1. Skema Berita & $\begin{array}{l}\text { Headline, lead, latar } \\
\text { informasi, kutipan sumber, } \\
\text { pernyataan, penutup. }\end{array}$ \\
\hline $\begin{array}{l}\text { SKRIP } \\
\text { Cara wartawan menyusun } \\
\text { fakta }\end{array}$ & 2. Kelengkapan berita & $5 \mathrm{~W}+1 \mathrm{H}$ \\
\hline $\begin{array}{l}\text { TEMATIK } \\
\text { Cara wartawan dalam } \\
\text { menulis fakta. }\end{array}$ & $\begin{array}{l}\text { 3. Detail. } \\
\text { 4. Koherensi } \\
\text { 5. Bentuk Kalimat } \\
\text { 6. Kata Ganti }\end{array}$ & $\begin{array}{l}\text { Paragraf, } \\
\text { kalimat, hubungan antar } \\
\text { kalimat. }\end{array}$ \\
\hline $\begin{array}{l}\text { RETORIS } \\
\text { Cara wartawan } \\
\text { menekankan fakta }\end{array}$ & $\begin{array}{l}\text { 7. Leksikon } \\
\text { 8. Grafis } \\
\text { 9. Metafora }\end{array}$ & $\begin{array}{l}\text { Kata, idiom, gambar/foto, } \\
\text { grafik. }\end{array}$ \\
\hline
\end{tabular}

Sumber : (Eriyanto, 2002)

Metode analisis framing yang dapat dilihat adalah bagaimana cara media memaknai, memahami dan membingkai kasus/peristiwa yang diberitakan. Metode 
semacam ini tentu saja berusaha mengerti dan menafsirkan makna dari suatu teks dengan jalan menguraikan bagaimana media membingkai isu. Peristiwa yang sama bisa jadi dibingkai berbeda oleh media. Ada beberapa model framing yang digunakan dalam menganalisis teks media. (Flora, 2014)

Video YouTube BBC News Indonesia yang berjudul "Dilema Ibu Kota Baru: Selamatkan Jakarta, Korbankan Kalimantan dan wawancara kepada narasumber merupakan teknik pengumpulan data dalam penelitian ini sebagai data primer. Data sekunder dalam penelitin ini yaitu referensi berupa buku-buku, artikel, jurnal serta situs internet sumber lain yang berkaitan dengan analisis framing. Untuk menguji validitas data penelitian ini menggunakan validitas data triangulasi sebagai teknik untuk mengecek keabsahan data dan juga memperkaya data. Tringulasi data dalam penelitian ini peneliti mengecek keabsahan data baik dari video You Tube BBC News Indonesia yang berjudul "Dilema Ibu Kota Baru: Selamatkan Jakarta, Korbankan Kalimantan". Dengan keakuratan sesuai dengan framing Zhongdang Pan dan Ge rald M. Kosicki, serta keabsahan dalam video wawancara dengan pihak BBC News Indonesia.

\section{Landasan Teori}

Penelitian ini menggunakan teori kontruksi realitas sosial, teori yang di cetuskan oleh Berger dan Luckmann. Menurutnya hubungan antara manusia, sebagai produsen dan dunia sosial sebagai produknya, tetap merupakan yang dialektis. Artinya, manusia (tentunya tidak dalam keadaan terisolasi, tetapi dalam kolektivitas-kolektivitasnya dan dunia sosialnya, berinteraksi satu sama lain. Masyarakat merupakan produk manusia. Masyarakat merupakan kenyataan obyektif maupun subyektif. Manusia merupakan produk sosial. (Berger \& Luckmann, 1966).

Ada tiga macam typologi konstruktivisme: pertama, konstruktivisme radikal; kedua, realisme hipotetis: ketiga, konstruktivisme biasa.

1) Konstruktivisme radikal: hanya dapat mengakui apa yang dibentuk oleh pikiran seseorang. Bentuk itu tidak selalu representasi dunia nyata. Kaum konstruktivisme radikal mengesampingkan hubungan antara pengetahuan dan kenyataan sebagai suatu kriteria kebenaran. Pengetahuan bagi mereka tidak merefleksi suatu realitas ontologis obyektif, namun sebuah realitas yang dibentuk oleh pengalaman seseorang. Pengetahuan selalu merupakan konstruksi dari individu yang mengetahui dan tidak dapat ditransfer kepada individu lain yang pasif. Karena itu konstruksi harus dilakukan sendiri olehnya terhadap pengetahuan itu, sedangkan lingkungan adalah sarana terjadinya konstruksi itu. 
2) Realism hipotetis: menjelaskan pengetahuan adalah sebuah hipotesis dari struktur realitas yang mendekati realitas dan menuju kepada pengetahuan yang sebenarnya.

3) Konstruktivisme biasa: telah mengambil semua konsekuensi konstruktivisme dan memahami pengetahuan sebagai gambaran dari realitas. Kemudian pengetahuan individu dipandang sebagai suatu gambaran yang dibentuk dari realitas objek dalam dirinya sendiri. (Suparno, 1997)

Dari ketiga macam konstruktivisme, terdapat kesamaan di mana konstruktivisme dilihat sebagai sebuah kerja kognitif individu untuk menafsirkan dunia realitas yang ada karena terjadi relasi sosial antara individu dengan lingkungan atau orang di sekitarnya. Individu kemudian membangun sendiri pengetahuan atas realitas yang dilihat itu berdasarkan pada struktur pengetahuan yang telah ada sebelumnya. Konstrukivisme macam inilah dikenal dengan konstruksi sosial Berger dan Luckman. Konstruksi tersebut mendeskripsikan bahwa realitas sosial ini dikonstruksi untuk memberikan penekanan separasi pemahaman antara kenyataan dan pengetahuan. Realitas dapat diartikan sebagai upaya dari kualitas yang diakuisisi mempunyai eksistensi yang tidak tergantung pada kehendak sendiri. Sedangkan pengetahuan dapat didefinisikan sebagai realitas yang benar terjadi secara nyata dan terdapat karakter secara spesifik. Masyarakat dipandang sebagai dialektika antara data-data objektif dan makna-makna subjektif, yaitu sebagai bentuk dari interaksi timbal balik antara apa yang dialami masyarakat sebagai realiatas diluar dirinya (lembaga-lembaga yang di hadapi oleh individu). Dengan kata lain, segala realitas sosial mempunyai komponen esensial kesadaran akan hidup sehari-hari sehingga mampu melintasi peristiwa dan perjumpaanya dengan orang lain dalam membentuk kehidupan sosial. (Al-Hakim, 2020)

Adapun asal usul konstruksi sosial dari filsafat konstruktivisme yang dimulai dari gagasan-gagasan konstruktif kognitif. Dalam aliran filsafat gagasan konstruktivisme telah muncul sejak Sokrates menemukan jiwa dalam tubuh manusia, sejak Plato menemukan akal budi dan ide. Gagasan tersebut semakin lebih konkret lagi setelah Aristoteles mengenalkan istilah, informasi, relasi, individu, substansi, materi, esensi dan sebagainya. Ia mengatakan bahwa, manusia adalah makhluk sosial, setiap pernyataan harus dibuktikan kebenarannya, bahwa kunci pengetahuan adalah logika dan dasar pengetahuan adalah fakta. Inilah yang menjadi dasar yang kuat bagi perkembangan gagasan-gagasan konstruktivisme sampai saat ini. Mulanya Peter L. Berger dan Luckmann tidak memasukan media massa ke dalam variabel namun karena masyarakat berkembang ke arah yang lebih modern maka teori konstruksi realitas sosial milik Berger dan Luckmann menjadi tidak bermakna lagi. Kemudian teori konstruksi realitas sosial mengalami revisi dengan memasukkan media massa menjadi sebuah variabel. Hadirnya media massa mampu memperbaiki kelemahan dari proses konstruksi realitas sosial yang 
dianggap berjalan lambat. Substansi teori konstruksi realitas media massa merupakan alur informasi yang cepat dan luas sehingga konstruksi sosial juga berlangsung cepat dan menyebar secara merata. Realitas yang telah terkonstruksi mampu membentuk opini massa (Bungin, 2015).

Adapun substansi teori konstruksi sosial media massa menekankan pada sirkulasi informasi yang cepat dan luas sehingga konstruksi realitas sosial berlangsung dengan sangat cepat dan sebarannya merata. Realitas yang terkonstruksi itu juga membentuk opini masyarakat yang cenderung apriori dan sinis. (Tamburaka, 2012)

Penelitian ini melihat bahwa media massa dapat menciptakan kontruksi realitas sosial mengenai pemindahan Ibu Kota melalui pemberitaan di BBC New Indonesia dalam tayang Youtbenya. Media massa dalam hal ini berkontribusi terhadap perkembangan isuisu terkait sekaligus memberikan pengaruh terhadap pembentukan opini publik. Dapat dikatakan, bahwa media tidak sekedar menjadi pihak yang pasif dan netral, tapi media memilih hal tertentu untuk ditonjolkan, dan meminimalkan hal yang lain. BBC News dapat mengkontruksi melalui pemberitaannya kepada penonton mengenai pemindahan Ibu Kota, sesuai dengan pengertian dari Berger itu sendiri bahwa manusia dapat membuat atau mengkontruksikan berdasarkan keinginanya, Serupa dengan Eriyanto bahwa tujuan dari berita adalah bagaimana perusahaan media massa mengkontruksi realitas sosial melalui isi pemberitaan tersebut, dan terkandung sebuah ideology dan pandangan dari perushaan media massa tersebut, dalam hal ini peneliti masuk, sharing, dan mencoba berempati dengan media yang diteliti BBC News dalam tayangan Youtube dengan episode "Dilema Ibu Kota Baru: Selamatkan Jakarta, Korbankan Kalimantan dan bagaimana media BBC News mengkontruksi realitas melalui pemberitaan tersebut Analisis kontruksionis, peneliti mencoba memahami bagaimana BBC News Indonesia dalam tayangan YouTube dengan judul "Dilema Ibu Kota Baru: Selamatkan Jakarta, Korbankan Kalimantan”. memberitakan dengan cara tertentu (Eriyanto, 2002)

\section{Temuan Penelitian}

Framing secara sederhana merupakan analisis untuk mengetahui bagaimana suatu realitas (peristiwa, aktor, kelompok) dimaknai dan dikonstruksikan dalam makna tertentu oleh media (Sambo, 2019) Analisis framing ini dilakukan terhadap video yang berjudul "Dilema Ibu Kota Baru: Selamatkan Jakarta, Korbankan Kalimantan?", berdurasi 17 menit 24 detik yang diunggah pada 6 Maret 2020 di channel YouTube BBC News Indonesia. Dengan analisis framing model Zhongdang Pan dan Kosicki, peneliti berusaha meneliti bagaimana pembingkaian mengenai rencana pemindahan ibu kota Indonesia. Seperti pada tabel dibawah ini: 
Tabel 2

\begin{tabular}{|c|l|}
\hline \multirow{5}{*}{ Elemen } & $\begin{array}{l}\text { Hasil Pengamatan Video “Dilema Ibu Kota Baru: Selamatkan } \\
\text { Jakarta, Korbankan Kalimantan?" pada Channel YouTube BBC } \\
\text { News Indonesia }\end{array}$ \\
\hline Struktur Sintaksis & $\begin{array}{l}\text { BBC News Indonesia dalam videonya memandang isu } \\
\text { rencana pemindahan ibu kota sangat penting untuk } \\
\text { diberitakan dan mampu membingkai secara adil, terbuka } \\
\text { dan objektif dengan memberikan pernyataan dari dua sisi. } \\
\text { Pertama, BBC Indonesia menampilkan alasan-alasan } \\
\text { mengapa pemerintah mencanangkan pemindahan ibu kota } \\
\text { ke Kalimantan Timur. Kedua, BBC News Indonesia } \\
\text { menggambarkan bagaimana pendapat dan dampak yang } \\
\text { akan dirasakan masyarakat Kalimantan dari pemindahan } \\
\text { ibu kota baru. BBC mengangkat headline yang cenderung } \\
\text { menginformasikan tentang rencana pemindahan ibu kota } \\
\text { ke Kalimantan dari sisi dampak yang akan dirasakan oleh } \\
\text { beberapa masyarakat Kalimantan. }\end{array}$ \\
\hline Struktur Sintaksis & $\begin{array}{l}\text { BBC News Indonesia dalam videonya memandang isu } \\
\text { rencana pemindahan ibu kota sangat penting untuk } \\
\text { diberitakan dan mampu membingkai secara adil, terbuka } \\
\text { dan objektif dengan memberikan pernyataan dari dua sisi. } \\
\text { Pertama, BBC Indonesia menampilkan alasan-alasan } \\
\text { mengapa pemerintah mencanangkan pemindahan ibu kota } \\
\text { ke Kalimantan Timur. Kedua, BBC News Indonesia } \\
\text { menggambarkan bagaimana pendapat dan dampak yang } \\
\text { akan dirasakan masyarakat Kalimantan dari pemindahan } \\
\text { ibu kota baru. BBC mengangkat headline yang cenderung } \\
\text { menginformasikan tentang rencana pemindahan ibu kota } \\
\text { ke Kalimantan dari sisi dampak yang akan dirasakan oleh }\end{array}$ \\
\hline
\end{tabular}




\begin{tabular}{|c|c|}
\hline & beberapa masyarakat Kalimantan. \\
\hline Struktur Skrip & $\begin{array}{l}\text { Terlihat bahwa unsur yang ada dalam video BBC News } \\
\text { Indonesia memenuhi unusr } 5 \mathrm{~W}+1 \mathrm{H} \text {. (What) keputusan } \\
\text { pemerintah memindahkan ibu kota ke Pulau Kalimantan } \\
\text { dan Kekhawatiran warga Kalimantan. (Who) Terdapat } \\
\text { sebelas narasumber dalam, yaitu Heri Andreas, Irma, } \\
\text { Winda, Bambang Brodjonegoro, Kardi, Purwanti, Sofian, } \\
\text { Dahlia, Syukran Amin, Dedi Irawan, Isna. (Where) BBC } \\
\text { News Indonesia berkesempatan mengunjungi Kalimantan } \\
\text { Timur. (When) Video liputan dilakukan pada Oktober } \\
\text { 2019. (Why) BBC New Indonesia mengangkat video } \\
\text { mengenai rencana pemindahan ibu kota karena isu ini } \\
\text { memunculkan pro dan kontra diantara masyarakat. (How) } \\
\text { BBC News Indonesia mengemas bagaimana isu masih } \\
\text { memiliki banyak pekerjaan rumah yang harus diselesaikan } \\
\text { oleh pemerintah, sebelum memindahkan ibu kota baru ke } \\
\text { Kalimantan. }\end{array}$ \\
\hline Struktur Tematik & $\begin{array}{l}\text { Melalui videonya, BBC News Indonesia mampu } \\
\text { mengemas informasi mana yang perlu dikembangkan dan } \\
\text { mana yang diceritakan lebih detail yang besar sehingga } \\
\text { dapat terlihat jelas akan gambaran bagaimana isu rencana } \\
\text { pemindahan ibu kota baru dari jika dilihat dua perspektif. } \\
\text { BBC News Indonesia menggunakan tiga jenis koherensi } \\
\text { dalam menceritakan fakta di video "Dilema Ibu Kota Baru: } \\
\text { Selamatkan Jakarta, Korbankan Kalimantan?", yaitu: } \\
\text { Koherensi Kontras, Koherensi Kausalitas, Koherensi Aditif }\end{array}$ \\
\hline Struktur Retoris & $\begin{array}{l}\text { Pemilihan kata yang dimunculkan oleh BBC News Indonesia } \\
\text { cukup menunjukkan bagaimana pemaknaan wartawan } \\
\text { terhadap sebuah fakta atau realitas. Seperti kata } \\
\text { 'tenggelam', 'berimbas', 'terburuk', 'mengorbankan' dan } \\
\text { 'jebakan kematian'. Penekanan dari segi grafis juga } \\
\text { ditampilkan sejak awal video oleh BBC News Indonesia. } \\
\text { Selain itu, BBC News Indonesia melengkapi video "Dilema } \\
\text { Ibu Kota Baru: Selamatkan Jakarta, Korbankan } \\
\text { Kalimantan?" dengan menampilkan bagaimana keadaan } \\
\text { rumah warga Jakarta yang sering terkena banjir, }\end{array}$ \\
\hline
\end{tabular}




\begin{tabular}{|l|l|}
\hline menampilkan kunjungannya ke lokasi pembangunan ibu \\
kota di Kalimantan Timur bersama kepala Bappenas \\
Bambang Brodjonegoro, hingga berkunjung ke Suku Paser, \\
dan pusat rehabilitasi di Kalimantan. Tampilan ini menjadi \\
pelengkap peristiwa yang dibangun oleh BBC News \\
Indonesia.
\end{tabular}

Berdasarkan hasil analisis framing terhadap video rencana pemindahan ibu kota baru yang telah peneliti lakukan di atas, pembingkaian ini tentu melalui proses konstruksi. Realitas sosial dimaknai dan dikonstruksikan dalam makna tertentu oleh sebuah media. Pembingkaian yang dilakukan oleh BBC News Indonesia dalam isu tersebut dapat dilihat dari bagaimana BBC News Indonesia menentukan isu atau masalah yang terkait.

Penjelasan mengenai isu rencana pemindahan ibu kota ini lebih terinci dari hasil wawancara yang dilakukan oleh peneliti kepada informan Abraham Utama selaku Jurnalis BBC News Indonesia dan Produser dari video "Dilema Ibu Kota Baru: Selamatkan Jakarta, Korbankan Kalimantan?" pada 13 Agustus 2020 melalui e-mail:

"Ada keluhan atau kritik orang-orang adat atau pegiat lingkungan di Kalimantan terhadap rencana pemindahan ibu kota. Mereka menilai akan ada banyak yang dikorbankan jika proyek itu dijalankan. Di satu sisi, pengambil kebijakan dan arsitek tata kota menilai Jakarta tidak bisa lagi menjadi ibu kota, salah satunya karena penurunan muka tanah. Apakah ada konklusi dari diskursus yang berkembang dalam video itu? Yang jelas publik akhirnya bisa melihat isu pemindahan ibu kota dari dua perspektif. Tidak banyak media massa yang mampu dan mau menjalankan tugas pers ini." (Wawancara Abraham Utama, Jurnalis BBC News Indonesia, 13 Agustus 2020, melalui e-mail)

Dari penjelasan tersebut dapat dihubungkan bahwa BBC News Indonesia memilih untuk menonjolkan fakta tertentu, yakni dampak yang akan dirasakan oleh masyarakat Kalimantan dari proyek pemindahan ibu kota. Hal tersebut didukung dengan pemilihan narasumber dalam mengkonstruksi video tersebut. Penentuan narasumber, termasuk dalam salah satu upaya framing yang dilakukan oleh media. Dalam mengangkat isu rencana pemindahan ibu kota, Abraham Utama selaku produser berperan penting dalam penentuan narasumber. Hal ini disampaikan oleh beliau melalui wawancara yang dilakukan peneliti. 
"Narasumber dipilih berdasarkan kepentingan mereka dalam isu itu. Orang yang tidak berhubungan dengan proyek ibu kota tentu tidak akan kami wawancara. Sesederhana itu." (Wawancara Abraham Utama Jurnalis BBC News Indonesia, 13 Agustus 2020, melalui e-mail)

Meskipun BBC News Indonesia lebih banyak menonjolkan kutipan narasumber dari warga adat asli dan pegiat lingkungan di Kalimantan. Namun, melalui videonya BBC News Indonesia mampu memberikan ruang argumentasi kepada pihak-pihak sesuai kepentingan dalam isu tersebut dan memberikan jawaban dengan melibatkan narasumber lain seperti Kepala Bappenas Bambang Brodjonegoro sebagai narasumber yang memiliki peran penting dalam rencana pemindahan ibu kota baru.

Berdasarkan hal tersebut, BBC News Indonesia dapat dikatakan telah memenuhi unsur cover bothside dalam produk beritanya. Namun, jika merujuk pada framing, fakta yang lebih ditonjolkan oleh BBC News Indonesia adalah dampak dari pemindahan ibu kota ke Kalimantan. Secara keseluruhan, BBC News Indonesia membingkai videonya dengan memunculkan nilai berita berupa informasi. Hal ini didukung dengan adanya penekanan fakta lain selain alasan pemindahan ibu kota, tetapi memunculkan juga fakta bahwa masyarakat Kalimantan masih terancam persoalan sertifikat kepemilikan lahan dan deforestasi hutan.

1. BBC News Indonesia Membentuk Opini Khalayak Melalui Video "Dilema Ibu Kota Baru: Selamatkan Jakarta, Korbankan Kalimantan?"

Jika dilihat dari hasi analisis sintaksis, skrip, tematik dan retoris, kemampuan BBC News Indonesia dalam menyajikan teks-teks berita terkait rencana pemindahan ibu kota baru dalam videonya dengan berbagai macam penyajian, telah menggiring opini khalayak yang menonton tayangannya sehingga memunculkan sikap pro dan kontra terhadap isu tersebut. Dalam frame yang disajikan, BBC News Indonesia lebih melihat rencana pemindahan ibu kota dari dampak yang akan dirasakan warga adat asli dan pegiat lingkungan di Kalimantan. Sehingga video ini cenderung lebih menciptakan citra negatif terkait pemindahan ibu kota baru ke Kalimantan bagi khalayak.

Dalam videonya, terdapat beberapa kali pengulangan informasi, yang menandakan bahwa informasi tersebut sangat penting dan menggiring khalayak pada ingatan tertentu. Efek dari framing media menurut Eriyanto salah satunya ada menggiring khalayak pada ingatan tertentu. Dimana perangkat dari wacana berita dari pemakaian metafora, kata atau kalimat tertentu yang dapat memengaruhi khalayak pada perspektif tertentu dari realitas yang dikonstruksi (Eriyanto, 2002)

BBC News Indonesia melalui tayangannya di YouTube tidak hanya menjembatani, namun juga menjadi sumber informasi bagi masyarakat untuk menggali informasi-informasi bagi masyarakat yang menguatkan opini terkait rencana 
pemindahan ibu kota. Pertumbuhan dan pembuahan opini-opini publik adalah dari hadirnya media-media sosial. Media sosial menjembatani antara aspirasi publik dengan kritik-kritik baik subjek maupun objek kritik tersebut (Manik, 2018)

2. Konstruksi BBC News Indonesia Dalam Video "Dilema Ibu Kota Baru: Selamatkan Jakarta, Korbankan Kalimantan?"

Dalam konteks ilmu jurnalisme, realitas sosial dikonstruksikan dalam makna tertentu yang dikenal dengan sebutan news value (nilai berita) yang kemudian ditarik menjadi lebih spesifik yang dikenal dengan sebutan angle (sudut pandang) dalam menulis berita (Sudarman, 2008) Dalam isu rencana pemindahan ibu kota, BBC News Indonesia tidak mendukung dan tidak menentang rencana hal tersebut. BBC News Indonesia memaknai rencana pemindahan ibu kota baru sebagai suatu isu yang penting. Semua konten BBC baik untuk televisi, radio, maupun online di manapun, harus memenuhi kode etik dan nilai-nilai yang telah disusun. Kode etik dan nilai-nilai disusun untuk membantu para wartawan mengahadapi keputusan editorial yang sulit. Nilai-nilai tersebut adalah: imparsialitas, kebenaran dan akurasi, independensi, kepentingan publik, dan akuntabilitas kepada audiensi (BBC Indonesia, 2020).

Menurut Westerstahl, seperti dikutip Denis McQuail dalam bukunya, salah satu indikator berita yang berkualitas adalah objektivitas yang terdiri atas faktual yang dibentuk oleh unsur benar dan relevan, dan imparsial yang terdiri atas seimbang dan netral (Abrar, 2019) Dalam analisis framing, validitas tidaklah diukur dari objektivitas dan pembacaan peneliti atas teks berita. Tetapi lebih dilihat dari bagaimana teks berita menyimpan kode-kode yang dapat ditafsirkan dengan jalan tertentu oleh peneliti.

Berkaitan dengan ciri khas jurnalisme BBC News Indonesia, melalui videonya terkait pemindahan ibu kota baru terdapat nilai kebenaran dan akurasi, imparsialitas, independensi, kepentingan publik, dan akuntabilitas kepada audiensi. Video mengenai rencana pemindahan ibu kota baru yang dimuat oleh BBC News Indonesia mampu menjelaskan dengan lengkap apa yang terjadi, mengapa isu ini dinilai penting, meminimalkan kebingungan, melakukan secara maksimal menjawab keraguan yang muncul, dan mendorong audiensi untuk terlibat aktif.

Isi media memang didasarkan pada kejadian di dunia nyata, namun isi media menampilkan dan menonjolkan elemen tertentu, dan logika struktural media dipakai dalam penonjolan elemen tersebut, bahkan media tertentu cenderung membatasi dan menyeleksi sumber berita, menafsirkan komentar-komentar sumber berita, dan memberi porsi yang berbeda terhadap perspektif lain. Dalam videonya BBC News Indonesia menonjolkan berbagai dampak yang akan diraskan warga Kalimantan dengan menyeleksi narasumber berita dan memberi porsi yang berbeda terhadap perspektif lain. 
Berita dalam pandangan konstruksionis diibaratkan sebagai sebuah drama. Berita tidak menggambarkan realitas, melainkan potret dari arena pertarungan antara berbagai pihak yang berkaitan dengan peristiwa, mereka (media) berusaha untuk menonjolkan kerangka, pemikiran, perspektif, konsep dan klaim interpretative dari masing-masing dalam memaknai objek (Nastatih \& Rachmaria, 2020)

BBC News Indonesia melalui videonya sebagai media yang independen dan mengedepankan kepentingan publik memberi 'suara' pada yang tidak bisa 'bersuara' dalam upaya mencapai kesepakatan dari pihak pengkritik dan yang dikritik atau yang berpendapat dan penerima pendapat. Maka cara yang santun lebih diupayakan dalam menyampaikan gagasan, karena hal ini lebih menjamin keberhasilan interaksi komunikasi sosial dalam konteks berbahasa dan berbangsa (Muhsyanur, 2010)

\section{SIMPULAN}

Berdasarkan unsur sintaksis, skrip, tematik, dan retoris dalam perangkat framing model Zhongdang Pan dan Kosicki, peneliti menyimpulkan bahwa video "Dilema Ibu Kota Baru: Selamatkan Jakarta, Korbankan Kalimantan?” yang dimuat BBC News Indonesia lebih melihat rencana pemindahan ibu kota dari dampak yang akan dirasakan warga adat asli dan pegiat lingkungan di Kalimantan. Sehingga video ini lebih membentuk opini khalayak yang negatif terkait pemindahan ibu kota baru ke Kalimantan.

BBC News Indonesia melalui videonya membangun konstruksi realitas sesuai dengan kode etik dan nilai-nilai BBC yang telah disusun. Nilai-nilai tersebut adalah: kebenaran dan akurasi, imparsialitas, independensi, kepentingan publik, dan akuntabilitas kepada audiensi. Sehingga konstruksi video yang dimuat oleh BBC News Indonesia dapat dilihat dari dua sisi. Pertama, pemindahan ibu kota ke Kalimantan dilakukan karena Jakarta dianggap sudah tidak layak menjadi ibu kota Indonesia. Kedua, pemindahan ibu kota ke Kalimantan berdampak besar bagi warga adat dan hutan Kalimantan.

\section{DAFTAR PUSTAKA}

Abrar, A. N. (2019). Menatap Masa Depan Jurnalisme Indonesia. Yogyakarta: Gadjah Mada University Press.

Al-Hakim, L. (2020). Konstruksi Realitas Simbolik Makna "Islam Damai" dalam Program Damai Indonesiaku TVOne. In Thesis. UIN Syarif Hidayatullah Jakarta.

Berger, Peter L \& Luckmann Thomas, The Social Construction of Reality A Treatise in the Sociology of Knowledge, Penguin Books, First published in the USA 1966. 
Bungin, Burhan, Konstruksi Sosial Media Massa: Kekuatan Pengaruh Media Massa, Iklan Televisi, dan Keputusan Konsumen serta Kritik terhadap Peter L. Berger \& Thomas Luckmann, cet-3, Jakarta: Prenadamedia Group, 2015.

Defi, A. P. (2019). Framing Berita Deklarasi Kampanye Jokowi - Makruf Dan PrabowoSandi Pada Pilpres Tahun 2019 Di Media Online. Intelektiva, l(1).

Eriyanto. (2002). Analisis Framing Kontruksi, ideologi, dan Politik Media. LKiS Group.

Flora, E. (2014). Analisis Framing Berita Calon Presiden RI 2014 - 2015 Pada Surat Kabar Kaltim Pos Dan Tribun Kaltim. EJournal Ilmu Komunikasi, 2(3), 347-356.

Goffman Erving, Frame Analysis: As Esseay on the Organization of Experience, U.S.A:Harper COLOPHON, 1974.

Hutasoit, W. L. (2018). Analisa Pemindahan Ibukota Negara. Dedikasi, 19(2), 108-128.

Karman, K. (2013). Media dan Konstruksi Realitas. Jurnal Studi Komunikasi Dan Media, 16(1), 27. https://doi.org/10.31445/jskm.2012.160102

Leonarda Johanes R.S. (2013). Analisis Framing Pemberitaan Konflik Partai Nasional Demokrat (Nasdem) Di Harian Media Indonesia Dan Koran Sindo. E-Komunikasi, 01, 10.

Manik, T. S. (2018). Narasi Dalam Nalar Demokrasi + Tips Menulsi Artikel di Media Massa. Bogor: Guepedia.

Muhsyanur. (2010). Telaah Sarkasme Pada Judul Berita Dalam Surat Kabar Palopo Pos. Seminar Nasional PRASASTI II “Kajian Pragmatik Dalam Berbagai Bidang," 53(9), 1689-1699.

Nastatih, H., \& Rachmaria, L. (2020). PEMBINGKAIAN PEMBERITAAN DEMONSTRASI MAHASISWA DI GEDUNG DEWAN PERWAKILAN RAKYAT (Analisis Framing Robert M. Entman Pada Media Online Tribunnews.com Periode 23-24 September 2019). DIALEKTIKA KOMUNIKA: Jurnal Kajian Komunikasi Dan Pembangunan Daerah, 8(2), 78-85. https://doi.org/10.33592/dk.v8i2.681

Sambo, M. (2019). Media Relations Kontemporer: Teori dan Praktik. Jakarta: Kencana. 
Silalahi, S. A. F. (2019). Dampak Ekonomi Dan Resiko Pemindahan Ibu Kota Negara. Info Singkat, XI. No 16/(ekonomi dan kebijakan publik), 1-24.

Sobur, Alex. Analisis Teks Media: Suatu Pengantar untuk Analisis Wacana, Analisis Semiotika, dan Analisis Framing. Bandung: PT REMAJA ROSDAKARYA, 2009

Sudarman, P. (2008). Menulis di Media Massa. Yogyakarta: Pustaka Pelajar.

Suparno, Paul, Filsafat Konstruktivisme Dalam Pendidikan, Yogyakarta: Kanisius, 1997.

Tamburaka, Apriadi, Agenda Setting Media Massa, Jakarta: Rajawali Pers, 2012.

Https:/lipi.go.id/berita/pindah-ibu-kota-solusi-atau-masalah-baru/21764, diakses pada 23 Maret 2020

https://bbc.com/indonesia/indonesia-40490287, diakses pada 27 Maret 2020 